\title{
Cost Benefit Analysis of Climate Change Adaptation Strategies on Crop Production Systems: A Case of Mpolonjeni Area Development Programme (ADP) in Swaziland
}

\author{
Phindile Shongwe $^{1}$, Micah B. Masuku ${ }^{2} \&$ Absalom M. Manyatsi ${ }^{3}$ \\ ${ }^{1}$ P.O. Box 5234, Manzini, M200. Swaziland \\ ${ }^{2}$ Department of Agricultural Economics and Management, University of Swaziland, Swaziland \\ ${ }^{3}$ Department of Agricultural and Biosystems Engineering, University of Swaziland, Swaziland \\ Correspondence: Micah B. Masuku, Department of Agricultural Economics and Management, P. O. Luyengo, \\ Luyengo. M205, University of Swaziland, Swaziland. Tel: 268-7602-6557. E-mail: mbmasuku@uniswa.sz
}

Received: June 25, 2013 Accepted: November 18, 2013 Online Published: December 25, 2013

doi:10.5539/sar.v3n1p37 URL: http://dx.doi.org/10.5539/sar.v3n1p37

\begin{abstract}
Prolonged drought and floods as a result of climate change are a serious problem for households at Mpolonjeni ADP because their livelihood is mainly rainfedfarming. This is evident as there is high level of food insecurity, crop failure, poverty and hunger, which has forced many households to abandon farming and survive by food aid. The study was a descriptive survey aimed to identify private adaptation strategies to climate change and conduct a cost benefit analysis for the identified adaptation strategies. A stratified random samplingtechnique was used to select 350 households. Personal interviews were conducted using structured questionnaires. Data were analysed using descriptive statistics and cost benefit analysis where net present value (NPV) and internal rate of return (IRR) were used as decision rules. Adaptation strategies used were; drought resistant varieties, switching crops, irrigation, crop rotation, mulching, minimum tillage, early planting, late planting and intercropping. Switching crops had the highest NPV, where maize (E14.40) should be substituted with drought tolerant crops such as cotton (E1864.40), sorghum (E283.30) and dry beans (E292.20). The study recommends that households should grow drought tolerant crops such as cotton, sorghum and dry beans instead of maize. The government should provide irrigation infrastructure, such as dams, strengthen extension services and subsidise farm inputs in order to improve crop production.
\end{abstract}

Keywords: climate change, climate variability, cost benefit analysis, adaptation strategies

\section{Introduction}

Climate change is characterised by changes in precipitation patterns, rainfall variability, and increased temperatures, which has increased the country's frequency of droughts, occasional floods, wildfires, windstorms and hailstorms (Manyatsi et al., 2010). According to Brown (2011), Gamedze (2006) and Manyatsi et al. (2010), droughts were the most prevalent climate-related shocks reported in the lowveld. For the past four decades, the country has been hit by severe droughts in 1983, 1992, 2001, 2007 and 2008, cyclone Domonia in 1984 and floods in 2000 .

According to Gamedze (2006), household livelihood vulnerability baseline surveys conducted in 1998, 2002 and 2006 showed that the impact of droughts in the Lowveld was worse than the other regions. There has been a sharp decline in crop production levels and diversity in the country, which then affected the economy as it is highly dependent on agriculture. Climate change and variability effects have resulted in deterioration of livelihood for most people living in the Lowveld. Households have since stopped farming and are solely dependent on social interventions and have developed dependency syndrome. Manyatsi et al. (2010) stated that, $40 \%$ of the arable land in the Lowveld has not been cultivated for over 10 years. Manyatsi et al. (2010) further observed that rural communities are aware of climate change and variability, but not aware of the scientific cause. For this reason, farmers do engage in livelihood strategies to cope with climate change and variability such as selling livestock, urbanisation, mixed cropping, crop diversification, rain water harvesting and growing vegetables under irrigation. However, the current adaptation measures though useful, are not sustainable and the communities have a developed dependency syndrome as they rely on food aid (Nxumalo, 2011; Gamedze, 
2006).

Adaptation to climate change is not a new phenomenon, throughout human history, societies have adapted to natural climate variability, but the human-induced climate change has led to a new complex dimension to this age-old challenge (Hachigonta, 2012). According to Burton et al. (2002) adaptation refers to the adjustment to ecological, social and economic systems done by individuals, groups or institutions in response to actual or expected climate stimuli and their effects or impacts. This involves changes in processes, practices or structures to moderate, offset potential damages or to take advantage of opportunities associated with climate change and variability. This enhances resilience and reduces vulnerability of communities as the people change their mix of production activities and the community rules and institutions in order to meet their livelihood needs.

In crop production, adaptation involves changes in management practices such as shifting planting dates, increasing fertiliser use, introduction of new plant varieties and use of irrigation systems to offset the effects of reduced precipitation and higher temperatures on yields. These strategies can be short or long run, private or public (Bruin, 2011; Callaway, 2003; Sathaye \& Christensen, 1998; Schipper, 2007).

A key strategy for managing risk and vulnerability associated with climate change is developing and implementing evidence-based policies and programmes that respond to local realities and priorities. For adaptation to be successful, it should be taken within a comprehensive and interactive process of social institutions and organizational learning and changes.

Challenges faced by smallholder farmers cannot be overlooked as they form $70 \%$ of the people living in rural areas in Swaziland and they manage vast areas of land, but make up the largest share of undernourished.They are the most vulnerable and marginalised, often lack secure tenure and resource rights. Smallholder farmers on Swazi Nation Land (SNL) are facing the challenge of low agricultural productivity due to several factors including climate change. According to Manyatsi et al. (2010), rural households are adapting to climate change, however the issue of poverty and hunger has not been fully addressed by such attempts as many people still rely on food aid. The question might be that, are these farmers using economic strategies or are they using these strategies the right way? Such questions cannot be fully addressed until these adaptation strategies are evaluated in terms of their efficiency. To address this concern, the study uses a cost benefit analysis to evaluate the adaptation strategies used by households in order to identity the most economic and practical strategies. The main objective of the study was to examine the costs and benefits of climate change adaptation strategies used by farmers in crop production, the specific objectives were to; (1) Identify private (action by farmers) adaptation strategies implemented at Mpolonjeni; and (2) Quantify the costs and benefits of private adaptation strategies to climate change at Mpolonjeni.

\section{Literature Review}

\subsection{Impacts of Climate Change on Crop Production}

Climate is a primary factor for agriculture productivity, such that any environmental change affects plant and animal production. Climate change has resulted in increased temperatures, which increase transpiration and evapotranspiration rate causing severe water stress as plants lose a lot of water and soil moisture is depleted (Aydinalp \& Cresser, 2008). The effect of increased temperature depends on the crop's optimal temperature requirements for growth and reproduction such that if warming exceeds a crop's optimum temperature, yield declines (Clair \& Lynch, 2010). Reduced soil moisture decreases available water for irrigation as water level from water sources decrease, and it becomes more difficult to meet plant water demand even by irrigation.

During droughts, plant roots are underdeveloped and unable to absorb nutrients and mineral from the soil. Reduced soil moisture decreases the amount of dissolved nutrients, increase concentration of nutrients making them toxic, and increases salinization. Droughts reduce soil fertility by reducing the organic component of the soil as the amount of crop residues is reduced. Leaching of soil nutrients occur during floods and high intensity rainfall. This has a negative impact on plant growth as plants suffer from nutrients deficiency syndrome. High rainfall intensity is one major cause of soil erosion. This removes the top nutritious soils and reduces nutrients available to plants and therefore reduces productivity (Clair \& Lynch, 2010).

Climate change alters the distribution, incidence, intensity of pests, diseases and invasion of alien species. High temperatures coupled with wet conditions create new niches and favours growth of pests and pathogenic organisms (FAO, 2008). Droughts and floods kill animals that are used by small scale farmers for ploughing, thereby leaving them with no choice, but to hire tractors. However, most rural households do not afford such services because of their poor financial background. Planted areas are therefore reduced and food insecurity increases forcing them to rely on food aid. 


\subsection{Adaptation Strategies and Adaptation Programmes to Climate Changein Crop Production}

Adaptation strategies to climate change can be private and public sector adaptation. Private adaptation strategies involve action taken by non-state agencies such as farmers, communities or organizations, firms in response to climate change perceived by them based on a set of available technology and management options. Private adaptations are implemented by farmers only when they considered them cost effective. These include switching crop, shifting crop calendar, management practices that suit the new climate, changing irrigation scheme and selecting different technologies. Public adaptation involves actions taken by local, regional and or national government to provide infrastructure and institutions that reduce the negative impact of climate changes. Public adaptation strategies include modernization or development of new irrigation infrastructure, transport or storage infrastructure, land use arrangements and property rights, water shed management institutions (Bruin, 2011; World Bank, 2010).

According to Sathaye and Christensen (1998), Bruin (2011), adaptation strategies can be either proactive or anticipatory depending whether adaptation takes place before or after climate change. Reactive adaptation address problems linked to climate change after they have been observed while proactive adaptations anticipate future problems and put solutions in place beforehand. In crop production, reactive adaptations include soil erosion control, dam construction for irrigation, soil fertility maintenance, development of new varieties, shifting planting and harvesting time. Anticipatory adaptations involve development of tolerant cultivars, research development, policy measures on taxation and incentives.

Enhancing adaptive capacity would reduce vulnerability to climate change and promotes sustainable development. Improving access to financial resources would allow farmers to buy farm inputs and equipment and this therefore, increases production and reduces poverty. Improving education and information would help disseminate information on climate change adaptation strategies and improve awareness of potential benefits of adaptation. Farmers can adapt by using drought resistant and early maturing seeds whichenable crops to escape long dry spells towards the end of the growing season. Providing infrastructures such as building dams enable farmers to irrigate during drought periods or supplement rainfall during and within the growing season which provide water for the plant. Improving roads make it easy for farmers to access markets for their produce and are able to buy inputs (IPCC, 2007).

Nhemachena and Hassan (2007) point outthat meteorological agency provides households with necessary information to use when planning for crop production. Research and development in the agriculture sector, disseminates appropriate technology and ensure that cheap technologies are available for smallholder farmers. Smallholder farmers can adapt to climate change by changing planting dates and diversifying crops (Gbetibouo, 2009). Yesuf et al. (2008) added that smallholder farmers can adapt to climate change by practicing soil and water conservation measures and planting trees. According to Mudzonga (2011), households adapt to climate change by crop diversification, using drought resistant crops, crop rotation, mulching, minimum tillage, intercropping, conservation agriculture and climate smart agriculture.

\subsection{Climate Change and Its Mitigation}

Mitigation focuses on the reduction of greenhouse gas emission or enhancing their removal from the atmosphere, while adaptation reduces the negative changes resulting from global warming and enhance beneficial impacts (Bruin, 2010). Mitigation through forestry and agriculture is the most important mitigation strategy for developing countries as they do not contribute much in greenhouse gas emission (Bryan et al., 2008).

According to Manyatsi et al. (2010), mitigation strategies in Swaziland include; investing in renewable energy, intensifying energy policies, and enforcing switching off lights and other electrical appliances in public institutions, enforcing legislation of cutting down trees, reducing veld burning, funding mitigation projects on methane capture, bringing services to people to reduce long distance transportation, installation of solar systems in all public buildings, installation of efficient appliances in all public places, improving wiring to and installation of smart devices to enable switching off lights when not in use, promoting energy efficiency in industries, licensing conditions to favour fuel switch in industry from coal to biomass, natural gas and methane.

\subsection{Conceptual Framework}

\subsubsection{Cost Benefit Analysis}

Cost benefit analysis is an economic analysis to aid social decision-making and is used to evaluate the desirability of a given intervention or interventions. It is a formal discipline used to help appraisal or assess projects and informal approach to making decisions of any kind to establish whether a proposed public or private investment is worthwhile (Kingston, 2001). The method compares all costs and benefits that can be expressed in 
monetary terms. To indicate the most efficient method, net present values, cost benefit ratios or internal rates of returns for the adaptation strategies were compared.

The conceptual framework in Figure 1 shows the linkage between climatic variables with agricultural production, hence food security. Climate change influence the policies governments make and the adaptation strategies adopted by victims of climate change. Existing policies and institutions also influence the households' susceptibility to climate change. Climate change affects crop yield and the livelihood patterns of households depending on adaptation strategies put in place

According to Smit and Pilifosova (2001), adaptation strategies determine the productivity of ecosystems and the food security status of the households. A low agricultural production and productivity due to climate change has implications on households' livelihoods and food security. Food security exist when all people, at all times, have physical and economic access to sufficient, safe and nutritious food to meet their dietary needs and food preferences for an active and health life (FAO, 1996). Food availability is a function of domestic production, distribution, storage, imports and exports. In most cases food availability is used as a measure of food security.

The conceptual framework was developed on the bases that climate change has an impact on agriculture. To improve on this situation, households adapt to the changed climate with the aim of reducing the effects. However, to achieve maximum yields, the adaptation strategies must be assessed to identify the most economic and effective adaptation strategies. Cost benefit analysis is used to evaluate the strategies such that improved yields can be realised even if there are negative impacts of climate change. This also allows farmers to choose the most efficient strategy.

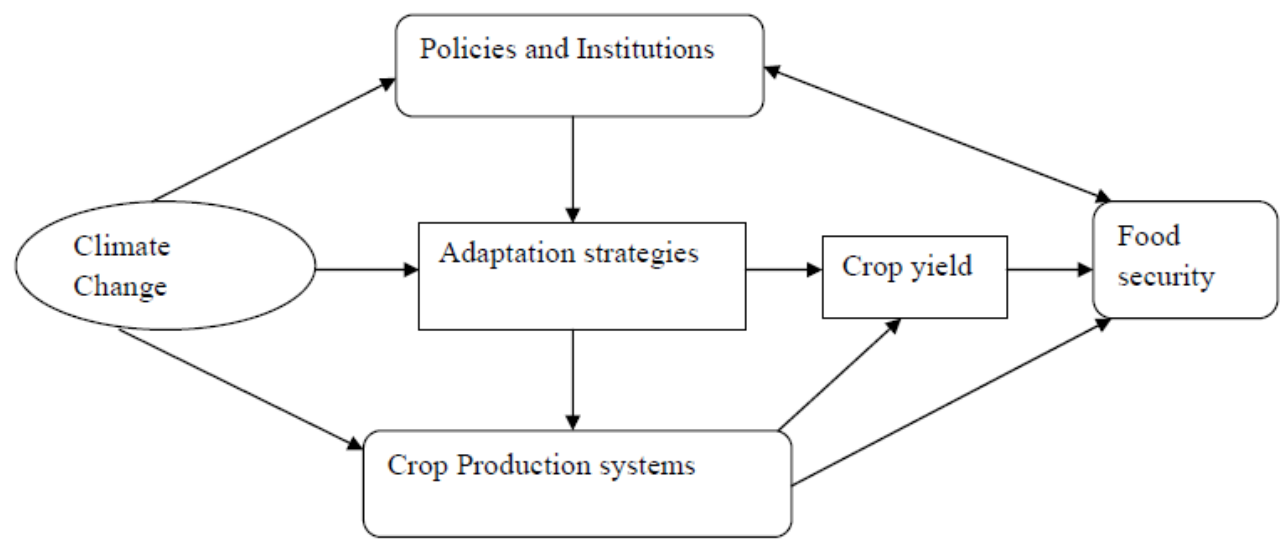

Figure 1. Conceptual framework

\section{Methodology}

\subsection{Study Design}

The study used a descriptive quantitative research design and describes adaptation strategies employed by households. It analyses adaptation strategies using a cost benefit analysis to identify the most effective and economic strategies.

\subsection{Study Area}

Mpolonjeni Area Development Programme of Swaziland (ADP) is located in the central east of Swaziland in the Lubombo administrative region and in the Lowveld ecological zone (Figure 2). It consists of two constituencies; Mpolonjeni constituency and Lugongolweni constituency. The ADP has five chiefdoms (communities) which are Mpolonjeni, kaLanga, kaNgcina, kaShoba and kaNdzangu.

The area receives $500-900 \mathrm{~mm}$ of rainfall per annum which occurs in summer and occasionally in winter. This is far less than the optimum water requirement for most crops. Household livelihoods depend on rainfed subsistence farming, which is characterised by low yields and frequent crop failure due to adverse effects of climate change and climate variability amongst many other factors.

The study area has an altitude of $303 \mathrm{~m}$ above sea level and is undulating plain to gently undulating plain. The 
soils range from red loam to red clay soils and are good for crop production except for root crops. Average minimum temperatures are $15.4{ }^{\circ} \mathrm{C}$ and the maximum temperature are $28.3^{\circ} \mathrm{C}$ (Vilakati, 1997).

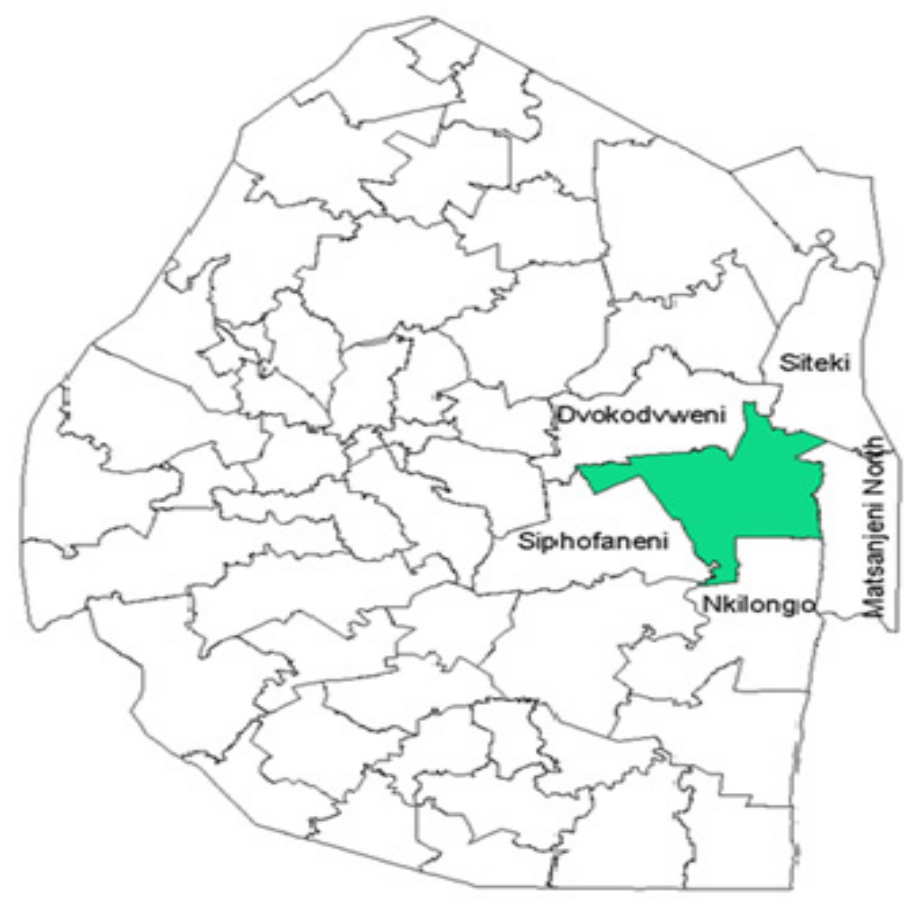

Figure 2. Map of Swaziland showing Mpolonjeni ADP

The community has reported a high increase in temperatures for the past decades which has reduced crop production and livestock feed pastures. For the past years, households have reported maize yields of 0.2 tonnes per hectare or no harvest at all (Nxumalo, 2011). As a result of the high temperatures, erratic, less frequent and unreliable changes in rainfall patterns, low intense rainfall in the area, farmers are more vulnerable to climate change. Climate variability reduces productivity and negatively affects the weather-dependent livelihood systems of the farmers. This makes the area to be a representative sample of areas that are negatively affected by climate change in the country.

\subsection{Target Population and Sampling Procedure}

The target population was 3157 households at the Mpolonjeni ADP. The households were composed of smallscale farmers practising subsistence rainfed and mixed farming on communal land. Astratified random sampling technique was used to obtain cross-sectional data from a sample of 350 households where chiefdoms (communities) were used as strata.Table1 presents the breakdown of the sample. However, from this sample only 257 households were producing crops, hence analysis was based on these households.

Table 1. Population and sample size of households from the chiefdoms of Mpolonjeni ADP

\begin{tabular}{lll}
\hline Chiefdom (Community) & Population size & Sample size \\
\hline Mpolonjeni & 614 & 68 \\
Langa & 1645 & 183 \\
Ngcina & 157 & 17 \\
Shoba & 441 & 49 \\
Ndzangu & 300 & 33 \\
Total & $\mathbf{3 1 5 7}$ & $\mathbf{3 5 0}$ \\
\hline
\end{tabular}




\subsection{Data Collection Procedures}

Data were obtained from 2011/2012 cropping season. The data were collected using personal interviews with an aid of a structured questionnaire. Secondary data from World Vision and Food Agriculture and Natural Resource Policy Analysis Network (FANRPAN) database which were collected in 1999 were also used.

\subsection{Data Analysis}

A Cost-benefit analysis for the different adaptation strategies was conductedusing net present values (NPV) and internal rate of returns (IRR). A high NPV indicates the most efficient and economic adaptation strategy. Similarly an adaptation strategies with the highest IRR were the most economical compared to those with low IRR.

\subsection{Analytical Framework}

The CBA focuses on the quantitative evaluation of climate change impacts on crops and allows for estimation of the net benefits of different adaptation options and is used to assess adaptation options when efficiency is the only decision making criteria. This involves calculating and comparing all the costs and benefits expressed in monetary terms (Bruin, 2010). This approach identifies the most economic adaptation strategy and allows ranking all the proposed strategies based on economic efficiency. Net present values are preferred because they discounts the future benefits to present values, whilst internal rate of returns are used to evaluate the most economic adaptation strategy. This can be done by;

i) Identifying the adaptation strategies employed in the communities.

ii) For each adaptation strategy, the total costs incurred when using that strategy and benefits were identified and to compute the net benefit for that particular adaptation strategy.

$\mathrm{NB}=\sum \mathrm{TB}-\sum \mathrm{TC}$

Where;

NB represents the net benefits (E)

TB represents the total benefits (E)

TC represents the total costs (E)

For adaptations that do not have direct costs and benefits, the shadow pricing and opportunity costs were used to quantify computed.

iii) The NPV as computed as;

The Net present Value $=\mathrm{NPV}=\sum\left(\mathrm{B}_{\mathrm{t}}-\mathrm{C}_{\mathrm{t}}\right) /(1+\mathrm{r})^{\mathrm{t}}$.

Where;

$\mathrm{B}_{\mathrm{t}}=$ Total benefits in year $\mathrm{t}$

$\mathrm{C}_{\mathrm{t}}=$ Total costs in year $\mathrm{t}$

$\mathrm{r}=$ Discount rate

$(1+r)^{t}=$ Discount factor for year $\mathrm{t}$

The adaptation strategy with a positive and highest NPV is the most economic and efficient. Sensitivity test was carried out, where the net benefit was discounted at 5\%,10\% and $15 \%$. The NPV was computed based on per hectare average returns. IRR is the discount rate at which NPV is zero. The strategy with the highest IRR is preferred.

\section{Results and Discussion}

\subsection{Descriptive Statistics of Respondents}

Table 2 presents the socioeconomic characteristics of household heads. The percentage of male headed households was $68.5 \%$, hence $31.5 \%$ were females. This indicates that in the households, the final decision makers were males and this has an implication on decision making regarding adaptation strategies to climate change and farming practices.

According to Nhemachena and Hassan (2007), female headed households are more likely to take up adaptation options as most of rural farming is done by women, while men are based in towns and cities. Women therefore, have more farming experience and information on management practices and how to change these practices than men. However, women are particularly vulnerable to poverty and have less access to education than men. 
Constitutionally in Swaziland, women control land and their finances, but contrary to this traditional social system discriminates against them and prevent them from owning and controlling land. Such discrimination to women can have a negative impact when adopting climate change strategies. This is because wealth and education are important determinates of adaptation strategies where wealth and education have a positive implication to adoption (Gbetibouo, 2009).

Considering the age of the household heads, $61.9 \%$ were above 50 years old. The majority of the household heads belong to non-active age group, which can have a negative bearing on adopting climate change adaptation strategies. This age group cannot provide much labour, but have farming experience.

Table 2. Descriptive statistics of respondents in Mpolonjeni ADP $(n=257)$

\begin{tabular}{|c|c|c|}
\hline Item & Frequency & Percentage \\
\hline \multicolumn{3}{|l|}{ Sex } \\
\hline Male & 176 & 68.5 \\
\hline Female & 81 & 31.5 \\
\hline \multicolumn{3}{|l|}{ Age group } \\
\hline 19 - 30 years & 7 & 2.7 \\
\hline $31-40$ years & 34 & 13.2 \\
\hline $41-50$ years & 57 & 22.2 \\
\hline Above 50 years & 159 & 61.9 \\
\hline \multicolumn{3}{|l|}{ Marital status } \\
\hline Married & 173 & 67.3 \\
\hline Single & 16 & 6.2 \\
\hline Divorced & 4 & 1.6 \\
\hline Widowed & 57 & 22.2 \\
\hline Separated & 7 & 2.7 \\
\hline \multicolumn{3}{|c|}{ Education level of household head } \\
\hline Illiterate & 143 & 55.6 \\
\hline Primary school level & 44 & 17.1 \\
\hline Junior secondary level & 35 & 13.6 \\
\hline Senior secondary level & 24 & 9.3 \\
\hline Professional college certificate & 8 & 3.1 \\
\hline University education & 1 & 0.4 \\
\hline Adult education & 2 & 0.8 \\
\hline \multicolumn{3}{|l|}{ Occupation } \\
\hline Full time farming & 99 & 38.5 \\
\hline Salaried employment & 78 & 30.4 \\
\hline Non agribusiness & 24 & 9.3 \\
\hline Casual farm work & 20 & 7.8 \\
\hline Casual off farm work & 1 & 0.4 \\
\hline Household chores & 35 & 13.4 \\
\hline
\end{tabular}

The percentage of married household heads was $67.3 \%$ and this implies that a major of the household heads had customary land property rights. The results indicate that full time farming is the major occupation despite the fact that it is subsistence farming. Moreover, most farming is rainfed as the results show that $96.9 \%$ of the 
households were not irrigating. The results show that more than half of the household heads were illiterate (55.6\%) and this makes it difficult for most household heads to understand new farming systems and technologies. Analysis was done to identify the amount of land used for the different adaptation strategies. The results of the analysis are presented in Table 3 below.

Table 3. Amount of land used for different adaptation strategies for 2011/2012 cropping season

\begin{tabular}{ll}
\hline Item & Area (ha) \\
\hline Type of seed & \\
Hybrid seeds & 300.0 \\
Traditional seeds & 1061.0 \\
Total & $\mathbf{1 3 6 1 . 0}$ \\
Type of watering system & \\
Irrigation & 92.0 \\
Rainfed & 1269.0 \\
Total & $\mathbf{1 3 6 1 . 0}$ \\
Minimum tillage & \\
Minimum tillage & 207.0 \\
Convectional agriculture & 1154.0 \\
Total & $\mathbf{1 3 6 1 . 0}$ \\
Crop rotation & \\
Groundnuts & 4.5 \\
Maize & 1361.0 \\
Total & $\mathbf{1 3 6 5 . 5}$ \\
\hline
\end{tabular}

From the results, 1361 ha are used for maize despite the fact that the maize yields are low in the region. Hybrid seed varieties in maize only cover 300 ha, while traditional varieties cover 1061 ha as households indicated to be using yields from previous crops as seeds for the next season. Crop rotation, where maize is rotated with groundnuts is not practiced by many households because the land used for groundnuts ( $4.5 \mathrm{ha})$ is far less than that used for maize (1361 ha). Minimum tillage is practiced on 207 ha while convectional cropping is on 1154 ha. From the cultivated land, $90.4 \%$ is used for maize (Zea mays), $6.1 \%$ for cotton (Gossypium spp), $2.2 \%$ for beans (Phaseolus vulgaris), $0.7 \%$ for sorghum (Sorghum bicolour) and $0.3 \%$ for groundnuts (Arachis hypogaea) and $0.2 \%$ is for cowpeas (Vigna unguiculata).

\subsection{Adaptation Strategies Employed by Households}

Sofoluwe, Tijani and Baruwa (2011) indicated that agriculture is negatively affected by climate change, while adaptation reduces the impact and increase resilience to climate change such that those farmers who adapt are less vulnerable to these negative impacts of climate change. Adaptation strategies employed by households are indicated on Table 4. Although the majority of the households interviewed claimed to be using one or more types of adaptation option only $4.7 \%$ were not using adaptive measures.

The results indicate that the majority $(68.9 \%)$, of the households were adapting by using drought resistant varieties, early planting (66.9\%) and late planting was used by $42.0 \%$. This suggests lack of access to improved varieties due to financial constraints or unavailability in the area. Sixty six percent of the households were taking advantage of the early rains as indicated by the results compared to late planting. Depending on the crop maturity days, early planting can ensure that critical plant growth stages do not coincide with very harsh climatic conditions. However shortage of farm machinery might be a major cause of those who did not adopt this option. 
Table 4. Adaptation strategies used by households in response to climate change and variability

\begin{tabular}{lllll}
\hline Adaptation strategy used & $\begin{array}{l}\text { Frequency } \\
\text { (Did use) }\end{array}$ & $\begin{array}{l}\text { Percentage } \\
\text { (Did use) }\end{array}$ & $\begin{array}{l}\text { Frequency } \\
\text { (Did not use) }\end{array}$ & $\begin{array}{l}\text { Percentage } \\
\text { (Did not use) }\end{array}$ \\
\hline Drought resistant varieties & 177 & 68.9 & 80 & 31.1 \\
Early planting & 172 & 66.9 & 85 & 33.1 \\
Late planting & 108 & 42.0 & 149 & 58.0 \\
Minimum tillage & 32 & 12.5 & 225 & 87.5 \\
Crop rotation & 47 & 18.3 & 210 & 81.7 \\
Mulching & 22 & 8.6 & 235 & 91.4 \\
Irrigation & 8 & 3.1 & 249 & 96.9 \\
Switching crops & 17 & 6.6 & 240 & 93.4 \\
Intercropping & 84 & 32.7 & 173 & 67.3 \\
No adaptation & 12 & 0.0 & 0 & 4.7 \\
\hline
\end{tabular}

Adaptation strategies that received the least responses were mulching, irrigation, crop rotation and minimum tillage. Irrigation involves high capital investment, which can be a challenge to most rural households because of poor financial background. The strategy also needs a good, reliable water source, which is not the case at Mpolonjeni as there are no major rivers nearby and water harvesting by earth dams has not been fully exploited.

\subsection{Cost Benefit Analysis}

\subsubsection{Cost Benefit Analysis for Adapting by Shifting Crops From Maize to Drought Tolerant Crops}

A minimal $(6.6 \%)$ number of households reported that they have adapted to climate change by shifting to drought resistant crops. These were sorghum, cotton and beans. However, they still do not grow these crops at larger scales and so maize still dominates because it is a staple crop. The results are presented in Table 5. The crop that has the highest NPV is cotton and this implies that when planting cotton, the benefits would be more than the costs by E1864.40 for each household while maize will give E14.40 on average. Compare with maize all the other crops had higher net present values. It is suggested that households should consider switching maize for drought tolerant crops based on the computed NPV. However this has to be compare to the other strategies. The sensitivity analysis shows that even if the discounts rate can change to 5 or $15 \%$ the NPV for the different crops still be positive.

Table 5. Net present value and internal rate of returns for switching crops from maize to drought tolerant crops

\begin{tabular}{|c|c|c|c|c|c|c|c|}
\hline Crop & $\begin{array}{l}\text { TC } \\
\left(E^{\prime} 000\right)\end{array}$ & $\begin{array}{l}\text { TR } \\
\left(E^{\prime} 000\right)\end{array}$ & $\begin{array}{l}\text { NB } \\
\left(E^{`} 000\right)\end{array}$ & IRR\% & $\begin{array}{l}\text { NPV 10\% } \\
\text { (E) }\end{array}$ & $\begin{array}{l}\text { NPV 5\% } \\
\text { (E) }\end{array}$ & $\begin{array}{l}\text { NPV 15\% } \\
\text { (E) }\end{array}$ \\
\hline Maize & 542.0 & 563.5 & 21.5 & 96.2 & 14.4 & 15.1 & 13.7 \\
\hline Sorghum & 5.6 & 9.3 & 3.7 & 6.1 & 283.3 & 296.8 & 271.0 \\
\hline Cotton & 148.3 & 338.0 & 189.7 & 43.9 & 1864.4 & 1953.2 & 1783.3 \\
\hline Drybeans & 3.3 & 14.1 & 11.4 & 23.7 & 292.2 & 306.1 & 279.5 \\
\hline Groundnuts & 3.5 & 4.9 & 1.4 & 72.4 & 284.6 & 298.5 & 272.2 \\
\hline Cowpeas & 0.2 & 1.1 & 0.9 & 19.0 & 252.3 & 264.3 & 241.3 \\
\hline
\end{tabular}

The IRR for cotton, dry beans, groundnuts and cowpeas are higher than that of maize and this implies that they are more beneficial than maize.

\subsubsection{Cost Benefit Analysis for Using Drought Resistant Crop Varieties Over Traditional Varieties}

The NPV for these varieties is calculated based on the average revenue for those using drought resistant crop varieties and those producing their own traditional seeds. 
The NPV for those producing their own seeds was lower than those using drought resistant varieties (Table 6). This is because most rural households are financially challenged and they cannot afford most the inputs including hybrid varieties. The households are using the previous harvest as seeds for the next season. The results show that the NPV for using drought resistant crops is higher than the NPV for using traditional seeds. The sensitivity analysis also shows that drought resistant varieties have higher NPV. The IRR for drought resistant varieties is higher than traditional seeds.

Table 6. Net present values and internal rate of returns for using drought resistance varieties

\begin{tabular}{|c|c|c|c|c|c|c|c|}
\hline Adaptation system & $\begin{array}{l}\text { TC } \\
\left(E^{\prime} 000\right)\end{array}$ & $\begin{array}{l}\text { TR } \\
\left(E^{\prime} 000\right)\end{array}$ & $\begin{array}{l}\text { NB } \\
(\mathrm{E}, 000)\end{array}$ & $\begin{array}{l}\text { IRR } \\
(\%)\end{array}$ & $\begin{array}{l}\text { NPV (10\%) } \\
\text { (E) }\end{array}$ & $\begin{array}{l}\text { NPV (5\%) } \\
\text { (E) }\end{array}$ & $\begin{array}{l}\text { NPV (15\%) } \\
\text { (E) }\end{array}$ \\
\hline Drought tolerant variety & 299.4 & 306.5 & 7.1 & 97.6 & 21.7 & 22.7 & 20.8 \\
\hline Traditional seeds & 246.0 & 257.0 & 11.0 & 96.0 & 12.3 & 12.9 & 11.8 \\
\hline
\end{tabular}

\subsubsection{Cost-Benefit Analysis for Using Irrigation Compared to Non-Irrigation}

Table 7 shows the NPV and IRR for irrigated and non-irrigated maize. The NPV for irrigation was more than rainfed, indicating that those who were irrigating had more revenue than those not irrigating. The households use fuel engines to supplement rainfall during the planting season. The reason might be that irrigation requires high initial cost which rural subsistence farmers cannot afford. This would require household to get loans and credits from financial institutions in order to afford an irrigation system. Such services are not easily provided to dry land farming because they have no collateral. The area does not have major rivers nearby, such that sourcing irrigation water become expensive. The few that are irrigating rely on earth dams and seasonal streams. Acquiring a good and sustainable irrigation system would need the intervention of government and non-governmental organisations because of the high cost involved. The IRR shows that for the cost to equal the returns, the discount rates should be changed to over $90 \%$. This shows these strategies cannot be easily affected by changes in discount rates.

Table 7. Net present value and internal rate of returns for irrigation

\begin{tabular}{llllllll}
\hline Adaptation system & TC & TR & NB & IRR & NPV 10\% & NPV 5\% & NPV15\% \\
& $\left(\mathbf{E}^{`} \mathbf{0 0 0}\right)$ & $\left.\mathbf{E}^{`} \mathbf{0 0 0}\right)$ & $\mathbf{( E ^ { \prime } \mathbf { 0 0 0 } )}$ & $\mathbf{( \% )}$ & $\mathbf{( E )}$ & $\mathbf{( E )}$ & $(\mathbf{E})$ \\
\hline Irrigation & 127.2 & 171.8 & 44.6 & 74.0 & 440.3 & 451.3 & 403.6 \\
Rainfed & 391.7 & 434.8 & 43.1 & 90.0 & 30.8 & 32.3 & 28.3 \\
\hline
\end{tabular}

\subsubsection{Cost-Benefit Analysis for Crop Rotation}

Households (18.3\%) indicated that there are using crop rotations as an adaptation strategy. Crop rotation was done with groundnuts and maize. Groundnuts being legumes add nitrogen to the soil, therefore increasing the soil fertility. Shadow pricing was used to estimate the amount of fertility change brought by legumes fixing nitrogen. This is calculated as a proportion of the fertilizer applied by the households per hectare. Average amount of fertilizer applied by the households is $75 \mathrm{~kg} / \mathrm{ha}$ and assuming that the legume will reduce the amount applied by $30 \%$. The net benefit would be E157.50/ha. The net revenue is increased by E708.75.

Table 8. Net present value and internal rate of returns for rotating maize and groundnuts

\begin{tabular}{cccccccc}
\hline Adaptation strategy & $\begin{array}{c}\text { TC } \\
\left(E^{`} \mathbf{0 0 0}\right)\end{array}$ & $\begin{array}{c}\text { TR } \\
\left(E^{`} \mathbf{0 0 0}\right)\end{array}$ & $\begin{array}{c}\text { NB } \\
\left(E^{`} \mathbf{0 0 0}\right)\end{array}$ & $\begin{array}{l}\text { IRR } \\
(\mathbf{\%})\end{array}$ & $\begin{array}{l}\text { NPV 10\% } \\
(\mathbf{E})\end{array}$ & $\begin{array}{l}\text { NPV 5\% } \\
(\mathbf{E})\end{array}$ & $\begin{array}{l}\text { NPV 15\% } \\
(\mathbf{E})\end{array}$ \\
\hline Maize & 542.0 & 563.5 & 21.5 & 96.2 & 14.4 & 15.1 & 13.2 \\
Groundnuts & 3.5 & 4.9 & 1.4 & 72.0 & 284.6 & 298.5 & 260.9 \\
\hline
\end{tabular}




\subsubsection{Cost Benefit Analysis for Minimum Tillage}

Minimum tillage reduces the cost of ploughing and conserves moisture. These improved the water holding capacity for the soil, reduce evaporation and make more water available for the plants. However, most households are not using the right implement for minimum tillage such that the benefits are not maximised. Households are using hand hoes for digging and this makes the plant roots not to be deep enough, such that during very hot days, the plants easily wilt.

Table 9. Net present value and internal rate of returns for minimum tillage in maize field

\begin{tabular}{cccccccc}
\hline Adaptation strategy & $\begin{array}{c}\text { TC } \\
\left(E^{`} \mathbf{0 0 0}\right)\end{array}$ & $\begin{array}{c}\text { TB } \\
\left(E^{`} \mathbf{0 0 0}\right)\end{array}$ & $\begin{array}{c}\text { NB } \\
\left(E^{\prime} \mathbf{0 0 0}\right)\end{array}$ & $\begin{array}{c}\text { IRR } \\
(\mathbf{\%})\end{array}$ & $\begin{array}{c}\text { NPV 10\% } \\
(\mathbf{E})\end{array}$ & $\begin{array}{c}\text { NPV 5\% } \\
(\mathbf{E})\end{array}$ & $\begin{array}{c}\text { NPV 15\% } \\
(\mathbf{E})\end{array}$ \\
\hline Minimum tillage & 90.5 & 100.6 & 10.1 & 90.0 & 44.0 & 46.1 & 42.1 \\
Convectional tillage & 451.5 & 463.0 & 11.5 & 81.0 & 9.1 & 9.5 & 8.7 \\
\hline
\end{tabular}

To compare all the strategies, a summary of the NPV are presented in Table 10. The results indicate that planting drought tolerant crops was the strategy with the highest NPV, where maize was switched with cotton.

Table 10. Net present value and internal rate of returns for all adaptation strategies

\begin{tabular}{lll}
\hline Adaptation strategy & IRR(\%) & NPV (E) \\
\hline Switching crops (sorghum) & 6.05 & 1864.37 \\
Switching crops (cotton) & 43.9 & 283.33 \\
Switching crops (dry beans) & 23.4 & 292.16 \\
Switching crop (groundnuts) & 72.4 & 284.60 \\
Switching crops (cowpeas) & 97.6 & 252.27 \\
Irrigation & 74.0 & 440.34 \\
Crop rotation (maize and groundnuts) & 97.9 & 284.60 \\
Minimum tillage & 90.0 & 43.99 \\
Drought resistance varieties & 72.0 & 21.67 \\
\hline
\end{tabular}

Note: maize is the reference point, NPV $=14.4$ at $10 \%$ discount rate.

\section{Conclusions and Recommendations}

\subsection{Conclusion}

The most economic adaptation strategy is switching from maize to drought tolerant crops such as cotton, sorghum, dry beans. Crop rotation also gives a high NPV. Irrigation shows a high net present value, but households need government intervention as the cost of constructing irrigation systems as construction costs are high.

\subsection{Recommendations}

Not all adaptation strategies are economical, so households should consider those that have higher benefits and practical in their situations. It is recommended that households should consider planting drought tolerant crops such as cotton, sorghum, dry beans. These crops are marketable and they should sell them to buy maize as it is the staple crop. Irrigation can also be exploited as household should build earth dams to harvest water during heavy rainfall days to supplement rainwater during dry critical growth stages of their crops. Households should exploit all these adaptation strategies to full capacity in order to realise their benefits. As households have financial constraints, they should focus more on those that have lower costs such as switching crops, crop rotation, minimum tillage and drought resistant varieties.

\section{Acknowledgements}

The authors would like to acknowledge Food, Agriculture, and Natural Resources Policy Analysis Network 
(FANRPAN) for providing financial support for the research.

\section{References}

Aydinalp, C., \& Cresser, M. S. (2008). The Effect of Global Climate Change on Agriculture. American- Eurasian Journal of Agriculture and Environmental Science, 3(5), 672-676.

Brown, R. (2011). Parliamentary Role and Relationship in Effectively Addressing Climate Change Issues-Swaziland, January 2011, Mbabane, Swaziland.

Bruin, K. (2011). An Economic Analysis of Adaptation to Climate Change under Uncertainty. Unpublished Doctoral Dissertation, University of Wageningen, the Netherlands.

Bryan, E., Akpula, W., Ringler, C., \& Yesuf, M. (2008). Global Carbon Markets, Are There Opportunities for Sub-Saharan Africa? IPFRI discussion paper.Washington D.C.

Burton, I., Huq, S., Lim, B., Pilifosova, O., \& Schipper, E. L. (2002). From impacts assessment to adaptation priorities: the shaping of adaptation policy. Climate Change Policy, 2, 145-159. http://dx.doi.org/10.1016/S1469-3062 (02)00038-4

Callaway, J. M. (2003). Adaptation Benefits and Costs-Measurement and PolicyIssues Working Party on Global and Structural Policies.

Clair, S. B., \& Lynch, J. P. (2010). The Opening of Pandora's Box: Climate ChangeImpacts on Soil Fertility and Crop Nutrition in Developing Countries. Journal of Plant Soil, 335, 101-115. http://dx.doi.org/10.1007/s11104-010-0328-z

Crosson, P. (1997). Impacts of Climate Change on Agriculture. Recourses for the Future. Climate Issues Briefs No: 4.

Food and Agriculture Organization of the United Nations (FAO). (1996). Rome declaration on world food security.World Food Summit, 13-17 Nov. 1996, Rome, Italy.

Food and Agriculture Organization of the United Nations (FAO). (2008). Climate-Related Trans-Boundary Pests and Diseases.Climate Change, Energy and Food, High Level Conference on Food Security; The Challenges of Climate Change and Bioenergy, 3-5 June 2008, Rome, Italy.

Gamedze, M. (2006). Climate Change Vulnerability and Adaptation Assessments inSwaziland. UNFCCC African Regional Workshop on Adaptation, 21-23 September 2006, Accra, Ghana.

Gbetibouo, G. A. (2009). Understating Farmers' Perceptions and Adaptation to Climate Change and Variability: The Case of the Limpopo Basin. IFPRI, Discussion Paper, Washington, DC, International Food Policy ResearchInstitute.

Hachigonta, S. (2012). Generating Policy Options for Climate Change Adaptations.Swaziland Common Vision Workshop, Luyengo, Swaziland.

International Panel on Climate Change (IPCC). (2007). Global Warming. IPCC, Group I\&II. Retrieved from http://www.aususa.org/global_warming/science_and_impact/science/findings, 25/11/2012

Kingston, G. (2001). Cost Benefit Analysis in Theory and Practice. Australian Economic Review, 34(4), 478-487. http://dx.doi.org/10.1111/1467-8462.00217

Manyatsi, A. M., Mhazo, N., \& Masarirambi, M. T. (2010). Climate Variability and Change as Perceived by Rural Communities in Swaziland. Research Journal of Environmental and Earth Sciences, 2(3), 165-170.

Mudzonga, E. (2011). Farmers' Adaptation to Climate Change in Chivu of Zimbabwe. Trade and Development Studies Centre, Belgravia, Harare, Zimbabwe.

Nhemachena, C., \& Hassan, R. M. (2007). Micro-level Analysis of Farmers'Adaptations toClimate Change in Southern Africa. IFPRI Discussion Paper No 714, Washington, DC.

Nxumalo, D. N. (2012). Community- perceived Household Vulnerability to Poverty in Mpolonjeni, Swaziland. Unpublished Master's thesis, University of Venda, South Africa.

Sathaye, J., \& Christensen, J. (1998). Mitigation and Adaptation Cost Assessment: Methods and Approach Use. UNEP Collaborating Centre on Energy and Environment, Riso National Laboratory, Denmark.

Schipper, E. L. F. (2007). Climate Change Adaptation and Development: Exploring the Linkages. Tyndall Centre Working Paper No. 107 July 2007.

Smith, B., \& Pilifosova, O. (2001). Adaptation to climate change in the context of sustainable development and 
equity, in climate change 2001: Impacts, adaptation and vulnerability, Chapter 18, Cambridge University Press.

Sofoluwe, N. A., Tijani A. A., \& Baruwa, O. I. (2011). Farmers' Perceptions and Adaptations to Climate Change in Osun State in Nigeria. African Journal of Agriculture and Research, 6(20), 4789-4794.

Vilakati, S. S. (1997). Geography for Swaziland. Macmillan Boleswa Publishers. Manzini, Swaziland.

World Bank. (2010). The Economics of Climate Change. A Synthesis Report. Final Constitution Draft. EACC.

Yesuf, M., Falco, D. S., Deressa, T., Ringler, C., \& Kohlin, G. (2008). The Impact of Climate Change and Adaptation on Food Production in Low-Income Countries: Evidence from the Nile Basin, Ethiopia, IPFRI Discussion Paper No. 828, Washington DC, International Food Policy Research Institute.

\section{Copyrights}

Copyright for this article is retained by the author(s), with first publication rights granted to the journal.

This is an open-access article distributed under the terms and conditions of the Creative Commons Attribution license (http://creativecommons.org/licenses/by/3.0/). 